\title{
Sciendo
}

DOI: $10.2478 /$ ejsta-2016-0002

\section{'Can God Make Acting Easy? A Reflection on the Characteristics of Acting Faciliter in Relation to Infused Moral Virtues' Lambert Hendriks}

\author{
Jaarboek Thomas Instituut te Utrecht 35 (2016), p. 35-48 \\ continued as \\ European Journal for the Study of Thomas Aquinas (2019 - ...)
}

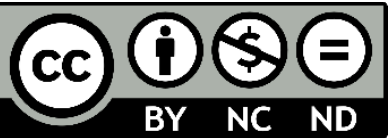

This work is licensed under a Creative Commons Attribution-NonCommercial-NoDerivatives 4.0 International License.

You are free to:

Share - copy and redistribute the material in any medium or format

The licensor cannot revoke these freedoms as long as you follow the license terms.

Under the following terms:

Attribution - You must give appropriate credit, provide a link to the license, and indicate if changes were made. You may do so in any reasonable manner, but not in any way that suggests the licensor endorses you or your use.

NonCommercial - You may not use the material for commercial purposes.

NoDerivatives - If you remix, transform, or build upon the material, you may not distribute the modified material. 


\title{
CAN GOD MAKE ACTING EASY? A REFLECTION ON THE CHARACTERISTICS OF ACTING FACILITER IN RELATION TO INFUSED MORAL VIRTUES
}

\author{
Lambert Hendriks
}

In recent times, unfortunately, martyrdom is brought again to the centre of our attention because of numerous massacres. Actuality can remind us sometimes of the old Christian persecutions, where the martyrs gloriously represented the courageous choice to remain faithful and to abstain even in extreme situations from evil actions. When we read the ancient acts of the trials of these martyrs and the description of their execution, we can be struck by the easiness and the joy that accompanies their martyrdom. This may bring us to the question: is becoming a martyr easy? Are the acts of the martyrs right when they describe a joyful and easy way towards death? We might be tempted to attribute such a description to a writer's pious memory of great saints. But still, we may consider the act of undergoing martyrdom as the ultimate example of virtuous acting, as Christian tradition holds ${ }^{1}$. In this context, martyrdom becomes an example of considering the effects of virtue in relation to God's aid in human acting. Is God's grace, undoubtedly present in a courageous martyr, able to provide easy acting by a human person? Among the characteristics of virtue, an essential aspect is that it makes the human action immediate, joyful and also easy ${ }^{2}$. However, when we reflect on these well-known characteristics of virtue in relation to martyrdom, it immediately becomes clear that some problems emerge.

Particularly the example of martyrdom shows us that doing good is about much more than mere human standards. After all, voluntarily

\footnotetext{
${ }^{1}$ This is mentioned often in John Paul II's encyclical Veritatis splendor (e.g. nrs. 90-94). See also: Catechism of the Catholic Church, 2473.

${ }^{2}$ These three characteristics are discussed e.g. in: R. Cessario, The Moral Virtues and Theological Ethics, Notre Dame 2009², 47. They are derived from Thomas's description of the virtue's habitus in: De virt q. 1, a. 1.
} 
undergoing death is not at all prudent according to inner-worldly values. It is only in the light of God and by His grace that martyrdom can become virtuous and exemplary ${ }^{3}$. For Thomas Aquinas, the fact that good acting always includes the perspective of the ultimate end and the necessity of God's grace, brings him to consider virtue not only in the Aristotelian sense of acquiring a good habit, but also - and perhaps foremost - in the Augustinian sense of an infused good habit of the soul as a grace: this is the problem of the infused moral virtues, as we are discussing it in this volume.

While acquiring a virtue, the habit brings about immediateness, joy and easiness in the virtuous act. Since this acquiring by repetitive acts is not typical in the case of infused virtue, the specific consequence of repetitive exercise, viz. easiness in acting, is not present in the same way as it is in acquired virtue. Martyrdom is a case in point. It is not difficult to imagine how the infused virtues, by God's grace, can cause an immediate and maybe even joyful human act, as the great stories of the martyrs show. But the example of martyrdom makes us wonder if this grace brings about also the characteristic of easy acting. No one, after all, would blame martyrs for finding it difficult to give up their own life, or for experiencing their heroic deed as something difficult. Indeed, this may show that the fact that virtuous acting is done 'faciliter' cannot in the same way be applied in the case of infused virtues. Such an infused virtue is not the result of a repetitive exercise of a specific action, making it easy to perform the latter ${ }^{4}$. But there is more to it. Specifically the martyrs do show us some kind of easiness in their martyrdom, which takes place on a different level. This is what this article will be about.

In what follows I would like to address this problem of acting 'faciliter' through infused moral virtues in three steps. Firstly, I will describe the convergence of the two definitions of virtue in

${ }^{3}$ Lee H. Yearley makes this point in "The Nature-Grace Question in the Context of Fortitude", in: The Thomist 35(1971), 577-578.

${ }^{4}$ This becomes even clearer in relation to actions that are contrary to prior habits: STh I-II, q. 65, a. 3 ad 2. 
Aquinas: the Aristotelian and the Augustinian one. Secondly, I will elaborate on the necessity of infused moral virtues and finally, with help of the prior elements, I will try to answer if God does indeed make virtuous acting easy.

\section{The convergence of the two definitions of virtue in Aquinas}

Looking at Aquinas's definition of virtue, it seems quite logical that this problem regarding the easy virtuous acting emerges. Aquinas has two different approaches when it comes to virtue: the Aristotelian one, where he defines virtue as an operative good habit $^{5}$ and the definition that is composed with texts of Augustine, who defines virtue as a "good quality of the mind, by which we live righteously, of which no one can make bad use, which God works

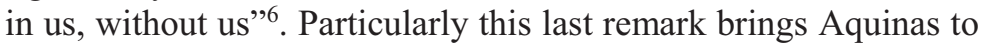
an explicit distinction between infused and acquired virtues. Comparing the two definitions, the first one relies heavily on the fact that the acting person has a good disposition, acquired by performing repetitively good acts, whereas the second definition attributes the possession of the virtue to God alone ${ }^{7}$. Evidently, the disposition to act good resulting from repeated free and reasonable action, causes also an easiness in acting. It has become a stable habit of the soul, caused by the acting person herself ${ }^{8}$. However, if virtues are possessed by infusion, they aren't preceded by actions that gently form the virtuous disposition in the person. This means that there is no ground on which the virtuous acts, based on infused moral virtues, would be performed easily.

${ }^{5}$ STh I-II, q. 55, a. 3: "Unde virtus humana, quae est habitus operativus, est bonus habitus, et boni operativus."

${ }^{6}$ STh I-II, q. 55, a. 4.

${ }^{7}$ Cf. STh I-II, q. 55, a. 4; I-II, q. 63 and De virt q. 1, aa. 1-2. See also:

L. Elders, De ethiek van Thomas van Aquino, Oegstgeest 2000, 161163.

${ }^{8}$ STh I-II, q. 63, a. 2: "Virtus igitur hominis ordinata ad bonum quod modificatur secundum regulam rationis humanae, potest ex actibus humanis causari, inquantum huiusmodi actus procedunt a ratione, sub cuius potestate et regula tale bonum consistit." 
Although Aquinas is explicit about the existence of both acquired and infused moral virtues (STh I-II, 55,4), still this difference has often been neglected or not always been accepted by everyone ${ }^{9}$. The reason for this hesitant approach is plausible, since the concept of "virtue" is in its common understanding usually related to the Aristotelian idea of repeated human action. In other words, if there exists a form of divine grace that is infused in persons in order to act good, why should this grace be related to virtue $?^{10}$ The answer to this question appears only in the situation where one abstains from a separation between the two types of virtue, just as Thomas Aquinas treats the two definitions harmoniously together. Both the Aristotelian and the Augustinian perspective shouldn't be separated ${ }^{11}$.

There is a convergence between both definitions of virtue, which allows for both approaches to be genuine human action, as well as to be the result of grace. Nowadays it is obvious that both grace and nature should not be considered as separated levels, and it is in calling the infused principle in relation to human action truly a "virtue", that this unity becomes conceivable. In other words, precisely the fact that also the infused moral virtues are just as much authentic elements in the human act of an acting person itself, makes them genuine virtues.

It is also because of the convergence between the two approaches of virtue, that infused moral virtues do not imply that the acting

${ }^{9}$ See also: S. Pinckaers, The Sources of Christian Ethics, Edinburgh 1995, 180; A. Pinsent, The Second-Person Perspective in Aquinas's Ethics. Virtues and Gifts, New York 2012, 66; R. Cessario, The Moral Virtues, 102.

${ }^{10}$ See also: A. Pinsent, The Second-Person Perspective, 18, where he refers to the opinion of J. Porter, and 64.

${ }^{11}$ As David Decosimo puts it: "Thomas ... structures the corpus to show that Augustine's definition clearly fits the Aristotelian conception of virtue", in: Ethics as a Work of Charity. Thomas Aquinas and Pagan Virtue, California 2014, 118. See also: G. Bullet, Vertus morales infuses et vertus morales acquises selon Saint Thomas d'Aquin, Fribourg 1958, 104. 
person loses her autonomy or her responsibility for her own acts ${ }^{12}$. The human act remains fully of the acting person herself. It is for this reason, that often the relationship is stressed between the human acts from infused moral virtues and those that stem from one's own natural disposition, or from acquired virtues. Aquinas clarifies that the part of (infused) virtue's definition, where it says that "God works in us, without us", does not mean that God takes over our actions. "God causes them in us, yet not without action on our part"13. Thomas clearly sees the action of God and the human action together: not only in the aforementioned sense that we have to consent to God's working in us, but also in the sense that our actions cause the right disposition, so that God is able to give the infused virtues ${ }^{14}$.

Looking at the way in which both acquired and infused virtues have their role in human action, it seems that infused virtue causes the disposition, the power for good conduct, whereas acquired virtue causes the action to be easy. For Gabriel Bullet these are two sorts of 'facilities': one essential, from the infused virtues, and one accidental, from the acquired virtues ${ }^{15}$, both present in the virtuous acting person. As he points out, these two types of facility remind of Aquinas's own distinction regarding the two ways of making action easy: one by prior exercise and one by a strong adherence to the object of virtue ${ }^{16}$.

${ }^{12}$ See also: D. Decosimo, Ethics as a Work of Charity, 134.

${ }^{13}$ STh I-II, q. 55, a. 4 ad 6: "Quae vero per nos aguntur, Deus in nobis causat non sine nobis agentibus".

${ }^{14}$ De virt q. 1, a. 11: "Actus autem nostri comparantur ad augmentum caritatis et virtutum infusarum, ut disponentes, sicut ad caritatem a principio obtinendam; homo enim faciens quod in se est, praeparat se, ut a Deo recipiat caritatem".

${ }^{15} \mathrm{G}$. Bullet, Vertus morales infuses, 115 .

${ }^{16}$ In IV Sent d. 14, q. 2, a. 2 ad 5: "facilitas operandi opera virtutum potest esse ex duobus; scilicet ex consuetudine praecedente; et hanc facilitatem non tribuit virtus infusa statim in sui principio: et iterum ex forti inhaesione ad objectum virtutis; et hanc est invenire in virtute infusa statim in sui principio". 
Bullet's way of describing the role of both types of virtues already hints to a solution for our problem regarding the acting 'faciliter'. That is to say that this characteristic is present not only in acquired virtues, but also in infused virtues, albeit in an unexpected way. In all the characteristics of virtue, grace and nature are working together. It is only plausible that this goes also for infusion and acquiring of virtues. In the complexity of a human act, both have their genuine place. In a classical way, this convergence is described with the words 'gratia supponit naturam', stressing that grace does not destroy the natural disposition. Particularly where it comes to human action, always the free human act should be preserved. In his article on nature and grace, Lee Yearley convincingly states that one should not overstress this aspect of nature being presupposed, in the sense that God is not bound to work in any particular way. However, in any normal situation God works in a continuity with natural human action, without radical interventions ${ }^{17}$. This continuity appears, hence, in a human act that is accomplished with all the normal human capacities, yet penetrated by God's grace.

Turning back to the question how infused moral virtues can make acting easy in the context of nature and grace, we have seen how there is a mutual dependency, or maybe better 'expectancy' of human nature and God's grace. This relationship is important in the discussion, although it has to be said that Aquinas himself does not say anything specific on the relationship between infused and acquired moral virtues ${ }^{18}$. In the whole of Aquinas's virtue ethics, however, the unity of human action and the unity of the acting person bestowed with grace, is always underlined, and from this follows for our initial question also the answer of an organic unity

${ }^{17}$ L. Yearley, "The Nature-Grace Question”, 574-575.

${ }^{18}$ See also: M. Sherwin, "Infused Virtue and the Effects of Acquired Vice: a Test Case for the Thomistic Theory of Infused Cardinal Virtues", in: The Thomist, 73(2009), 49. 
between acquired and infused virtues ${ }^{19}$. As concepts they can be separated, but in reality they coexist together.

Within this unity, both grace and nature act according to their specific essence. To say that they act in harmony is not quite sufficient, as there is a real penetration of human action by the supernatural grace. This is shown by Pinckaers in a clear way, when he explains how human action becomes able to have supernatural happiness as its end. It is the one human act, that gains a new perspective and becomes able to be an expression of Christian morality ${ }^{20}$.

\section{The necessity of infused moral virtues}

One of the problems in identifying the role of the infused moral virtues becomes clear when one analyses the acting of persons that don't have a corresponding acquired habitus in any way. Classical examples in this respect are young children who are baptised and thus receive grace, but also people with a vicious contrary habit who come to conversion and repent. Although it is clear that they do receive infused virtues ${ }^{21}$, it is clear at the same time that the corresponding act can never be easy to them, at least not in an evident way. The answer to this problem can be found in the fact that the infused moral virtues provide the disposition to act, and not the actual acting itself. This is what becomes even clearer when Aquinas reflects on infused virtue in young children and those

19 See also: R. Cessario, The Moral Virtues, 109; L. Melina, The Epiphany of Love. Toward a Theological Understanding of Christian Action, Cambridge 2010, 38. In this context also the connection of the virtues has its place.

${ }^{20}$ See: S. Pinckaers, Sources of Christian Ethics, 180: "These qualities penetrate the interior of the natural virtues, enabling them to act in view of supernatural happiness [...] Thus the infused moral virtues contribute to trace specific lines of Christian morality even at the level of the natural virtues".

${ }^{21}$ See M. Sherwin, "Infused Virtue", 34; G. Bullet, Vertus morales, 45, 50 and 136-137. See also the declaration of the Council of Vienna (1312) on the the effect of baptism: DH 903. 
deprived of the use of reason ${ }^{22}$. Virtues, after all, are not thus related to actual acting, that only persons who actualise this potentiality can be said to have virtues: virtues are habits of the soul, as is elaborated by David Decosimo in a clear way ${ }^{23}$.

In the previous paragraphs it has become clear that the infusion of virtues can coexist with the natural way of acquiring virtues, without posing a threat to the freedom of the acting person, nor to the logic of acquisition by repetitive good action. A further step in the line of reasoning should be, if the infusion of virtues is not only possible, but even necessary beyond the natural acquiring of virtues. Previously it turned out that infused moral virtues are a divine, yet also normal phenomenon in human action: they direct the human act to God. But if it is true that they change the perspective of action towards God and the ultimate end, then they can even be recognised as necessary elements. Acting in view of the ultimate end, after all, is the characteristic of truly good action: an end that the infused virtues have in view while choosing the means to that end. In fact, that the grace of this infusion is necessary to achieve our supernatural destination, is pointed out by Aquinas quite at the beginning of the Prima Secundae ${ }^{24}$.

Where God becomes a factor in human acting, He also provides a new perspective and a new end to every human act. This is precisely what happens when infused moral virtues are given.

${ }^{22}$ STh II-II, q. 47, a. 14 ad 3: "Sed prudentia gratuita causatur ex infusione divina. Unde in pueris baptizatis nondum habentibus usum rationis est prudentia secundum habitum, sed non secundum actum, sicut et in amentibus". See also: A. Pinsent, The Second-Person Perspective, 17 and 72, as well as: D. Decosimo, Ethics as a Work of Charity, 79.

${ }^{23}$ See: D. Decosimo, Ethics as a Work of Charity, 72-77 and 84. Here, Decosimo points out why virtue does not always immediately imply actual acting.

${ }^{24}$ STh I-II, q. 5, a. 5: "Unde nec homo, nec aliqua creatura, potest consequi beatitudinem ultimam per sua naturalia". See also: J. Wippel, "Natur und Gnade", in: A. Speer (Hrsg.), Thomas von Aquin: Die Summa theologiae. Werkinterpretationen, Berlin 2004, 250-251 and 256. 
However, the notion, that grace adds to human action the possibility of a new supernatural end, which motivates that very action, is not the only thing that there is to it. In his book on the Second-Person Perspective, Andrew Pinsent reacts to Sherwin's claim that the infused moral virtues provide the possibility to act rightly, with regard to the means to the ultimate end, which is $\operatorname{God}^{25}$. If I understand Pinsent correctly, he criticises the fact that the infused moral virtues would then be an unnecessary addition to the theory of action, since the direction towards God is already sufficiently given in the theological virtues. However, in Sherwin's position, the infused moral virtues should be considered beyond the mere function of providing a supernatural end to the human act, which is proper to the theological virtues. The infused moral virtues, while having their proper ends, have to do with the means to that ultimate end. With this remark, the contrast between the positions of Sherwin and Pinsent is resolved: the infused moral virtues don't copy the theological virtue's supernatural end, but provide the means to that end.

The virtues, being habits of the soul and present in the core of every human act, provide a connatural inclination towards the virtuous good ${ }^{26}$. This is also the case with the infused moral virtues. Just as the moral virtues are directed to particular goods, also the infused moral virtues provide for a new connaturality with particular goods that are eventually related to the ultimate end. In normal virtuous acting it is reason that establishes the concrete mean to an end by a virtuous inclination ${ }^{27}$; in the case of infused moral virtues this mean is still established by reason, but now by reason "enlightened by faith" 28 . In more recent discussions, e.g.

${ }^{25}$ See: A. Pinsent, The Second-Person Perspective, 68.

${ }^{26}$ See: STh I, q. 1, a. 6 ad 3; I-II, q. 58, a. 1 and 4.

${ }^{27}$ See also: R. te Velde, "De deugd als eenheid van natuur en rede. Over de habitus-leer van Thomas", in: R. te Velde (red.), De deugden van de mens. Thomas van Aquino: De virtutibus in communi, Baarn 1995, e.g. 90.

${ }^{28}$ See: J. Aumann, "Mystical Experience, the Infused Virtues and the Gifts", in: Angelicum 58(1981), 38 and 45; G. Bullet, Vertus morales infuses, 106. 
between McKay and Osborn, regarding the different possible forms of prudence (perfect and imperfect acquired prudence and infused prudence) it becomes clear that this role of reason is difficult to determine, particularly where it comes to the place of grace in it ${ }^{29}$.

Nonetheless, it is important to recognise the role of grace within the whole of reasonable virtuous acting, because it is the only way in which the human acts can become proportionate to their perfect end, which transcends a person's natural capabilities ${ }^{30}$. Many have pointed to this paradox of human agency, that a person desires by his natural powers something that only God can give. It is by recognising in the infused virtues a new proportionality that this paradox is overcome ${ }^{31}$. This new proportion means that the good that the acting person ultimately strives for, is not only the good that God provides, but that it has also become connatural to her. It is through the infused moral virtues that this connaturality and proportion can be experienced on the level of concrete human acts.

\section{Does God make acting easy by infused moral virtues?}

When we want to answer the question if God makes virtuous acting easy by means of the infused moral virtues, then with the aforementioned elements already a preliminary answer can be given: the acting person becomes able to act in a good way, because she can act for the perfect end - this is what Bullet called 'faciliter' as possible (see paragraph 1). Acting easy, after all, is based on a proportion that exists between the end of my actions and my own capabilities. So if God provides the means to act for the perfect end, then acting 'faciliter' has become a real characteristic. Through the

${ }^{29}$ See: A. McKay, "Prudence and Acquired Moral Virtue", in: The Thomist 69(2005), 535-555 and T. Osborne jr., "Perfect and Imperfect Virtues", in: The Thomist 71(2007), 39-64.

${ }^{30}$ See: J. Wippel, "Natur und Gnade", 246-270; L. Yearley, "The Nature-Grace Question", 564-565.

${ }^{31}$ E.g. R. Cessario, The Moral Virtues, 105; M. Sherwin, "Infused Virtue", 39; L. Melina, The Epiphany of Love, 78; G. Bullet, Vertus morales infuses, 121. 
infused virtues, a person's capabilities become in harmony with the end she should strive for and also the imperfection of nature's own limits can be overcome ${ }^{32}$. For Aquinas, the fact that God provides this proportion in human acts, is quite obvious. With a beautiful phrase, he states: "It is not fitting that God should provide less for those whom he loves with a view to their obtaining a supernatural good than for creatures whom he loves with a view to their obtaining a natural good" 33 .

This is the consequence of Thomas's vast affirmation that "acts conducing to an end must be proportionate to that end" and that, consequently, grace is needed to perform meritorious acts, proportionate to everlasting life ${ }^{34}$. This word "meritorious" that Aquinas adds, is important. When authors describe the reason for the existence of infused moral virtues, they often point to the fact that only because of these, a person can act meritoriously in view of the ultimate end ${ }^{35}$. Because of this characteristic, Sherwin and McKay point to Aquinas's affirmation that infused virtues only have to do with acts that regard the acting person's salvation (STh II-II, 47,14 ad 3) $)^{36}$. This proportion to the ultimate end is the first

${ }^{32}$ See also: R. te Velde, "De deugd als eenheid van natuur en rede", 130.

${ }^{33}$ STh I-II, q. 110, a. 2: "non est conveniens quod Deus minus provideat his quos diligit ad supernaturale bonum habendum, quam creaturis quas diligit ad bonum naturale habendum". See also: STh I-II, q. 65, a. 3: "Caritate simul infunduntur omnes virtutes morales. Cuius ratio est quia Deus non minus perfecte operatur in operibus gratiae, quam in operibus naturae".

${ }^{34}$ STh I-II, q. 109, a. 5: "Et ideo homo per sua naturalia non potest producere opera meritoria proportionata vitae aeternae, sed ad hoc exigitur altior virtus, quae est virtus gratiae. Et ideo sine gratia homo non potest mereri vitam aeternam”. See also: G. Bullet, Vertus morales infuses, 101.

${ }^{35}$ We can find this e.g. in: G. Bullet, Vertus morales infuses, 45; J. Wippel, "Natur und Gnade", 251; J. Aumann, "Mystical Experience", 37.

${ }^{36}$ M. Sherwin, "Infused Virtue", 42 and A. McKay, "Prudence and Acquired Moral Virtue", 554. 
argument to recognise a form of easiness in acting through infused moral virtues. It is not the 'faciliter' in the characterological sense, but the easiness is given through the adherence to the end. This adherence provides a 'drive' towards the end, present in the human act.

There is also a second and perhaps even stronger argument to recognise a certain easiness in acting through the infusion of virtues. Until now, we have described infused moral virtues primarily by means of the virtuous and gratuitous ordination towards the ultimate end in human action. We have seen some aspects that could be regarded as referring to a certain easiness in acting. For the second argument, we should recall one of the key features in Aquinas's theory of action and this has to do with the way in which difficulties can be overcome in acting. For Thomas, the fact that we need God's grace to achieve the ultimate end of our actions or that we need God to act good at all, does not degrade our own acting. What is more, he expressly states that "what we do by means of our friends, is done, in a sense, by ourselves" 37 . This theme, of course, fits beautifully within the reflection of "charity" as a friendship with God (STh II-II, 23,1).

Through this intrinsic relationship with God, the acting person who receives God's infused virtues, is now able to act - not merely by his own power - but by the aid of God, to whom acting obviously cannot but be easy. In this argument it is important that for Aquinas also seeking the help of others is a normal feature of one's own acting; this is the second-person perspective that Pinsent describes as "a way of conceiving how virtue ethics can be reconciled with divine direction without being reduced to an ethics of divine command"38.

In this way, the previous description of Bullet of the two forms of 'facility', is placed in a new light and applied to virtue as

${ }^{37}$ STh I-II, q. 5, a. 5 ad 1. See also: A. Pinsent, "The Second-Person Perspective", 73 and L. Melina, The Epiphany of Love, 21 and 153.

${ }^{38}$ A. Pinsent, The Second-Person Perspective, 73. See also: op.cit., 18 and A. McKay, "Prudence and Acquired Moral Virtue", 554. 
such. We have seen that not only acquiescence gives a "facilitas operandi", but the strong adherence to the object of virtue does this as well ${ }^{39}$. In infused moral virtues the latter is present as a principle of action, given by God, whose help is necessary to the acting person. It makes sense that technically, infused virtue does not provide easiness, because of the lacking of a repetition of the virtuous act. But in the order of the redemption of mankind, Christ appears as the friend that comes to the aid of the acting person, providing this "facilitas operandi", which is present in the infused moral virtues ${ }^{40}$.

Having introduced the role of Jesus Christ in the theory of action, it is evident that $\mathrm{He}$ is not a casual bystander in the history of salvation: His role is essential to human action. His incarnation made Him a brother and friend of every human being, and in that quality $\mathrm{He}$ is ready to provide the facility in human action, which is needed for acts in view to the ultimate perfection and salvation. The infused virtues are the practical ways of doing just that. Human acts that stem from these virtues, essentially are graced acts. This grace, then, flows from the the redemption that Christ brought about; it makes the acting person capable of participating in the work of salvation and of the imitation of Christ ${ }^{41}$. For a Christian, it is in this way that acquired and infused moral virtues are essentially related, and acts that are performed by acquired virtue at the same time stem from the infused virtue as well. Both the Christian and Christ himself can be recognised in the one human act.

\section{Conclusion}

God grants through the infused moral virtues, a very specific way of easy acting, or a "unique type of facility", as Sherwin calls $i^{42}$. He gives the ability to act for the true virtuous good, He gives the

\footnotetext{
${ }^{39}$ See the already quoted: In IV Sent d. 14, q. 2, a. 2 ad 5.

${ }^{40}$ See also: R. Cessario, The Moral Virtues, 119.

${ }^{41}$ See also: D. Decosimo, Ethics as a Work of Charity, 103; M. Sherwin, "Infused Virtue", 30-31; R. Cessario, The Moral Virtues, 108.

${ }^{42}$ M. Sherwin, "Infused vritue", 44-45.
} 
proportion and He gives also immediate, joyful and easy acting, even though it is very much possible that acquired contrary habits still have to be overcome. Answering the question if God makes acting easy, this appears to be the case. But the 'faciliter' as a characteristic of infused virtues has to be considered also in a broader, but still authentical sense. The infused virtues entail intrinsically the help of God in acting, making thus true good action possible in the first place, suitable to participate in salvation, which is every acting person's vocation. The easiness in acting is provided by a striving in human action, originating from the adherence to the supernatural end. This drive is given in the infused moral virtues, not by making the human contribution to the act futile, but as an aid to true human acting.

It is important to keep this broader picture, including the ultimate end, in mind, to see the function of the infused moral virtues. When it comes the theory of action, it is the organic whole that counts, and not the single elements of human agency ${ }^{43}$. If the acquired virtues would suffice, then our end would not be complete and perfect; if the infused virtues would suffice, then morality becomes unrealistic and inhumane. It is precisely because of this intrinsically joint perspective, that the martyrs in every age of Christianity can make for themselves the genuine human choice to follow the infused virtuous inclination to imitate Christ in a form of courage that they could never have thought of without God's help. Although in one way it is appropriate not to like becoming a martyr, it is precisely in the situation when we see people undergoing martyrdom in an immediate, joyful and apparently easy way, that we can recognise the infused virtues that lead us to salvation.

[Lambert Hendriks, Major Seminary of Rolduc, Heyendallaan 82, 6464 EP Kerkrade, The Netherlands; 1.hendriks@me.com.]

43 A. Pinsent, The Second-Person Perspective, 67, referring to S. Pinckaers. 